Article

\title{
Drawing the Line: Disability, Genetic Intervention and Bioethics
}

\author{
Adam Conti \\ Graduate student, Melbourne Law School, University of Melbourne, 185 Pelham St., Carlton, VIC 3053, \\ Australia; aconti@student.unimelb.edu.au
}

Received: 2 June 2017; Accepted: 10 July 2017; Published: 17 July 2017

\begin{abstract}
Meteoric scientific advances in genetic technologies with the potential for human gene editing intervention pose tremendous legal, medical, social, ethical and moral issues for society as a whole. Persons with disabilities in particular have a significant stake in determining how these technologies are governed at the international, domestic and individual levels in the future. However, the law cannot easily keep up with the rate of scientific progression. This paper aims to posit a methodology of reform, based on a core value of human dignity, as the optimal course of action to ensure that the interests of persons with disabilities, other possibly marginalised groups, and the scientific community, are balanced fairly. The paper critically analyses the current law and varying bioethical perspectives to ultimately conclude that a clear principled approach toward open discussion and consensus is of paramount importance to have any chance of devising an effective regulatory regime over human gene editing technology.
\end{abstract}

Keywords: disability; human rights; genetics; gene editing; bioethics; governance; human dignity; eugenics; germline; Convention on the Rights of Persons with Disabilities

The true good is in the different, not the same (Menand 2004).

\section{Introduction}

Popular, professional and scholarly interest in genetics and their influence on human variability, behaviour and development has grown exponentially in recent years. In no small part has this interest been bolstered by mainstream media coverage of large-scale collaborative scientific initiatives like the Human Genome Project, which endeavoured to identify and map the human genome and determine the sequence of nucleotide base pairs that make up our DNA. Even over a decade ago, the President's Council on Bioethics asserted that:

[W] have entered upon a golden age for biology, medicine, and biotechnology. With the completion of (the DNA sequencing phase of) the Human Genome Project and the emergence of stem cell research, we can look forward to major insights into human development, normal and abnormal, as well as novel and more precisely selected treatments for human disease ... In myriad ways, the discoveries of biologists and the inventions of biotechnologists are steadily increasing our power ever more precisely to intervene into the workings of our bodies and minds and to alter them by rational design (President's Council on Bioethics 2003, pp. 4-5).

Our knowledge and expertise in the realm of genetic engineering and methods through which to alter our genetic makeup have expanded exponentially since that statement. Science continually pushes the contemporary boundaries of what can be done just as much as it does for what we think should or should not be done. In 2017, we now have access to ground-breaking technologies that are becoming more accurate and inexpensive, and therefore more widespread. Human genome editing 
is one such practice that is rapidly advancing with the potential to outpace legal regulation at the national, international and institutional levels.

Atypical biotechnological advancement and (lack of) regulation poses a vast array of ethical, social, legal and human rights issues for the disability human rights movement. From one perspective, misuse of these technologies could quite quickly develop into a new eugenics movement akin to humanity's sordid and abominable forays into such immoral practices throughout history. From another, it beckons new horizons for the human race and promises of a 'better' human or a 'better' life for those already living with disabilities. This debate touches on notions of normality, discrimination and fundamental values of human dignity, and prompts a number of unsettling questions. Will society's attitudes towards and treatment of persons with disabilities become determinant purely on their genetic makeup? Will such people be further ostracised as a result of potentially not having 'desirable' genetic traits? Will there be active eugenic practices to 'eradicate' genetic disability? Most importantly, will there be a way to stop that from happening?

This paper aims to search for an answer to the last question so as to negate the need to ask the former ones. It contends that genomic technology, its use and development, should be appropriately regulated in the future so as to balance the interests of science with those of people with disabilities. Section 2 briefly elucidates humanity's abhorrent past of eugenic practices in the 20th Century. By tracking technological advancement in the human genetic modification sphere, it draws analogies between the two eras to shed light on the well-founded concern of some disability rights advocates that it risks delving into the realm of a 'neo-eugenics' movement. Section 3 canvasses the opposing bioethical theories that underpin various legal, medical, social, ethical and moral perspectives in this area. Section 4 explores and critically analyses the way in which the international community and individual nation states (particularly Australia) have attempted to effectively protect the interests of those with disabilities in light of these technological advances. Finally, Section 5 will propose a human rights model of reform to remedy flaws and omissions in the current regulatory system, such that disability rights advocates have a powerful and influential voice in shaping a genetic tool that has the capacity to shape how they live their lives.

Ultimately, the greatest obstacle for effective regulation is the undeniable fact that the rapid development of these technologies is unstoppable. However, the way in which they are used can be changed and controlled. With the implementation of appropriate international and domestic regulatory regimes that not only consider the past and present, but also comprise an element of foresight, persons with disabilities are less likely to be adversely affected. That is the rationale for this paper. Developing genetic technologies pose a crucial and eventually universal issue as they become more accessible and less expensive; undoubtedly the quickest way to their abuse.

\section{Classical and Neo-Eugenics}

Prevailing attitudes towards the 'other' are often influenced by the contemporary and prevailing social, political, cultural and technological developments at any point in human history. This section aims to track eugenics, as one such attitude, from its oldest form through to the current day in order to exemplify the issues that genetic technologies pose for people with disabilities.

\subsection{Classical Eugenics: How Far Have We Gone?}

Eugenics is not a new concept. The term's classical meaning was originally articulated by Francis Galton as:

the science of improving stock, which is by no means confined to questions of judicious mating, but [includes] all influences that tend in however remote a degree to give to the more suitable races or strains of blood a better chance of prevailing speedily over the less suitable than they otherwise would have had (Galton 1883, p. 17). 
Essentially, it constitutes a set of beliefs and practices that advocate for 'improvement' of the human race by the application of genetic laws based on Darwin's theory of evolution and Mendelian laws of inheritance (Somsen 2009). Galton's theories were influential, rapidly spreading to the United States and beyond (Black 2008). They eventually birthed government-sponsored eugenics movements across the world, which aimed to both encourage those considered to have 'good' heritable traits to have more children and discourage or expressly prohibit those thought to be 'unfit' from doing the same (Baruch et al. 2005, p. 34).

Disability rights advocates are troubled by historical eugenics because such policies were almost always directed towards groups that had, or were perceived to have, physical or mental impairments (Amundson and Tresky 2008, p. 113). The starkest and most barbarian example of these practices was the Nazi 'racial hygiene' policy, which actively sought to prevent Germans from reproducing with people considered to be 'biologic threats' given their 'inferior' genes (Bachruch 2004, p. 419). A further offshoot of this policy was the Aktion T4 program. Pursuant to guidelines from the government, the program required German doctors to administer an involuntary 'mercy death' by euthanasia to patients deigned to be 'incurably sick, by critical medical examination' (Proctor 1988, p. 177). People with disabilities, confined to a mental health institution or otherwise impaired were quickly categorised as such (Amundson and Tresky 2008, p. 113), aligning with the program's underlying policy of negative eugenic 'cleansing' (Breggin 1993). Ultimately, historians estimate that between 200,000-250,000 people with physical and intellectual disabilities were murdered under the Aktion T4 program between 1939 and 1945 (Herberer 2002, p. 62; Burleigh 1994).

Francis Fukuyama, a previous member of the President's Council of Bioethics, consequently condemned this chapter of history as 'the last important political movement to explicitly deny the premise of universal human dignity' (Fukuyama 2002, p. 156). The harsh impact of these practices can still be felt today, particularly in communities of those with disabilities. The past highlights the great importance of discouraging the use of genetics, or any other trait or characteristic, as a rationale for discriminating against any person or group (Bachruch 2004, p. 420). If nothing else, the Nazi era should serve as a bleak reminder that there is a slippery slope between a eugenic ideology and a human atrocity. The only thing needed to bridge the gap between them is a 'tool'. What is worrying is that this next tool might be here sooner than expected.

\subsection{Genomic Technology as Neo-Eugenics: How Far Have We Come?}

An impressive number of ground-breaking technological and scientific developments over the last 40 years have drastically developed the scientific community's ability to manipulate genetic material. Baldi believes that these developments signify 'the end of our evolutionary odyssey' (Baldi 2001, p. 163). We can now test embryos for genetic defects, gender and disease even before implantation through in vitro fertilisation procedures, investigate gene function in a plethora of organisms (Dzau and Cicerone 2015, p. 411) and, as emphasised in this paper, may soon have the ability to alter our fundamental genetic makeup, which may in turn be inherited by our offspring (Hoge and Appelbaum 2012, p. 1549). Genome editing is a type of genetic engineering that allows for flexible insertion, deletion or replacement of deoxyribonucleic acid ('DNA') in cellular organisms through the use of engineered nucleases (Ishii 2015, p. 1).

The most recently developed, highly exalted and technologically disruptive gene editing tool is the CRISPR-Cas 9 ('CRISPR') system. Essentially, CRISPR is a family of engineered nucleases based on segments of a bacterial defence mechanism that both identifies and removes foreign viruses from the bacterial genome as an adaptive immune response (Hsu et al. 2014, p. 1264). Small parts of the viral DNA sequences are left scattered between repeated bacteria DNA sequences, known as 'clustered regularly interspaced short palindromic repeats' (or CRISPR), so that the bacteria can more easily protect itself against the same virus in the future.

A key aspect of the adaptive immune response is the protein Cas9, which can seek out, cut and eventually degrade viral DNA (Doudna 2015). Put simply, scientists have determined how to 
harness Cas9's capabilities into a tool that enables an organism's genome to be 'cut' or spliced at any targeted location specified by 'guide' ribonucleic acid ('RNA') molecules (Dzau and Cicerone 2015, p. 411), whether they be 'as large as an entire gene [or] as small as a single nucleotide' (Altman et al. 2015, p. 25).

What makes CRISPR such an incredible development in genetics is that it allows edits to become significantly more efficient, accurate and cost-effective, whilst being less technically problematic than ever before (Esvelt and Wang 2013, p. 1; Ledford 2015, p. 21). Its usage in the scientific community is growing rapidly as a result. In April 2015, Chinese scientists reported results of an attempt to alter the DNA of non-viable human embryos using CRISPR to correct a heritable blood mutation that causes beta thalassemia (Liang et al. 2015). The experiments resulted in changing only some of the genes, and had off-target effects on other genes. The scientists who conducted the research stated that CRISPR is not yet ready for clinical application in reproductive medicine. Even so, a point was made: if those embryos had been viable, then implanted in a woman and been brought to term, we would have created genetically modified humans (Center for Genetics and Society and Friends of the Earth 2015, p. 22).

Nevertheless, as with any disruptive technology, this unprecedented advance in genetic engineering holds great promise for generational therapeutics, but has sparked a large social and ethical debate. That debate will be further explored through the lens of bioethics and disability human rights in Section 3. Suffice it to say for now that what is especially concerning is that edits can be made not only in adult somatic cells, but also in germline cells, such as those in embryos and gametes. The crucial difference between somatic and germline cells is that the former is idiosyncratic and any effects of an edit are limited to a single individual, whilst genome changes to the latter can be inherited by offspring, thus impacting future individuals' bodies and minds (Ishii 2015, p. 19). To that end, the National Academies of Sciences and Medicine released a consensus statement of the Committee for the International Summit of Gene Editing, which emphasises that the alteration of germline cells is irresponsible and could have far-reaching, unintended, or adverse consequences for human evolution; genetically, culturally and, in terms of disability human rights, socially as well (National Academies of Sciences and Medicine 2015). Furthermore, many scientists, including Jennifer Doudna, one of the inventors of CRISPR, have urged a worldwide moratorium on clinical application of CRISPR to human germline modification until the full implications of the technology 'are discussed among scientific and governmental organisations ... and interest groups' (Baltimore et al. 2015; Lanphier et al. 2015).

To take a step back and examine what such developments might mean for persons with disabilities is a difficult and controversial task. In October 2015, the UN International Bioethics Committee stated that the ethical problems of human genetic engineering should not be confused with the ethical problems of 20th Century eugenics movements; however, it is still problematic because it challenges the idea of human equality and opens up new forms of discrimination and stigmatisation for those with disabilities. It is true that the ethos of the current technological phenomenon contrasts with that of classical eugenics, given that to some extent it has been accepted that 'it makes no evolutionary sense to drive our species through a man-made bottleneck of genetic uniformity' (Brosius and Kreitman 2000, p. 253).

Nevertheless, there are strong parallels to be drawn between the eugenics era and the growing role of human genetic modification following the Human Genome Project. As already noted, classical eugenics was concerned with selecting certain people through forced sterilisation, restrictive reproduction laws and secret killings (Fischer 2012, p. 1097). The growing concern is that a neo-eugenics movement may be instead focused on the selection of certain genes (King 2001, pp. 171-72). There are fears that the allure of the doctrine of social advancement that the Council for Responsible Genetics has termed 'biological perfectibility' will result in organised neo-eugenics programs that slowly but surely aim to eradicate genes that cause disability, whilst inserting inheritable 'better' genes (Council for Responsible Genetics 2005). Though, at least in Australia, the idea of such government-sanctioned programs appears too remote a possibility, in the past legitimate concerns have been expressed by the President of the American Association of People with Disabilities: 
One would hope that reactions to the Holocaust and the advent of the disability rights and independent living movements in the U.S. and around the world would have put an end to the eugenic efforts to eliminate disabled people ... Unfortunately, if we examine the rhetoric of some influential modern scientists and ethicists, we can see the emergence of a new eugenics tied to the rapid advances in scientific understanding of the human genome (Imparato 2004).

Similar statements have been echoed by Disabled Peoples International (DPI), which highlights that:

Human genetics poses a threat to us because while cures and palliatives are promised, what is actually being offered are genetic tests for characteristics perceived as undesirable ... These technologies are, therefore, opening the door to a new eugenics which directly threatens our human rights ((Disabled Peoples International DPI, p. 3)).

These techniques may be aimed to eliminate disabling traits that are deemed 'abnormal', 'defective' or even 'cruel'. If disabling features in a foetus were to be seen as features that would render its life not worth living, then the same view would likely be taken for existing people already living with those same conditions (Jones 2011b, p. 103). Misapplication of genetic practice under such a pretence could quite clearly amount to eugenics. Notwithstanding that genetic disability does not account for all types of disability, such as those that are acquired through accident, injury and armed conflict, initiatives like the Human Genome Project could contribute to the creation of the notion of disability as deviance and people with disabilities, whether living or embryonic, as a different species whose lives are intrinsically less valuable than others (Turmusani 2004). If so, neo-eugenics would not be a retrospective regulation of living people, but rather a pre-emptive strike on unborn future generations (Witzany 2016, p. 281).

Furthermore, there are fears that human germline genetic modification will adversely affect human dignity and wider societal attitudes towards those living with disabilities, casting people as 'problems' that could have been avoided, and putting pressure on families to have genetically 'perfect' children (Baruch et al. 2005, p. 7). It is argued by Pollack that the negative end game of human germline modification is that those who have not had their genes modified, or who acquire disabilities or otherwise inherit them, will be born into a world 'with a complexity of genome different from what ... technology will be able to define as "normal" (Pollack 2015, p. 871). Neo-eugenics may therefore reduce persons with disabilities merely to their genetic makeup or origins, rather than as people of equal standing (Jones 2011b, p. 103; Iles 1996, p. 47). In a world where people with disabilities may already be considered by some as 'lesser', such a development would only serve to widen the gap that disability rights advocates must bridge. That sentiment is echoed by Baruch et al., who assert that the normalisation of genetic enhancement might 'decrease society's tolerance for and willingness to support and treat those living with disabilities'(Baruch et al. 2005, pp. 7, 27). Lander similarly highlighted the 'moral grayness' and eugenic practices that are inherent in genetic modification of human life (Lander 2015, p. 7). Ultimately, they conclude that CRISPR practice on human germlines can only proceed if there is a strong ethical argument to do so, or if necessity dictates it so. Otherwise, clinical practice should be banned.

In any case, the potential implications of human germline genetic modification for those with disabilities ultimately turn on the way in which tools such as CRISPR are utilised in the future. Will society be coerced (whether overtly or impliedly) into its widespread use, or will there be sufficiently effective and adaptable regulation that considers and protects disability human rights?

\section{Disability, Bioethics and Human Rights: Clash or Cooperate?}

How we conceptualise disability human rights and genetic technologies like human germline engineering and CRISPR tools frames the regulatory measures we believe are appropriate. To properly appreciate the current relevant law, and to ultimately point toward an appropriate model that balances human and scientific interests, we must first understand the human rights and bioethical principles that 
underpin various sides of this controversial debate. The discipline of bioethics is centred on the critical assessment of ethical and legal controversies that arise from emerging situations and possibilities brought about by advances in biological medicine (Smith 2012, p. 2). Therefore, it is pertinent to examine the three competing schools of thought on disability through an overarching bioethical lens:

(1) The traditional utilitarian medical model of disability;

(2) The pro-disability rights perspective of the social model;

(3) The human rights model of disability, a more recently emerging trend amongst disability rights scholarship.

As will become apparent in the following passages, one's bioethical perspectives and corresponding views on disability rights may affect their fundamental normative position on the issue of how technologies like CRISPR should or should not be used and regulated, and for what purpose. Generally, proponents of the medical model would be more open to the use of a less regulated CRISPR for curative purposes. In the same way, those who propound the social and dignitarian models may be more inclined to its opposition and greater regulation, in the former case on grounds of possible further systemic disadvantage to persons with disabilities, and in the latter case due to the threat of harm to their human dignity.

This paper asserts that it is a regulatory framework founded on the human rights model, or at the very least, a combination of the social model and human rights model, that best protects the rights and interests of people with disabilities in the face of rapid genetic technology advancement.

\subsection{The Medical Model and Beneficence}

Throughout history, people with disabilities have unfortunately been treated by some as tragic burdens and objects of pity by society (Kayess and French 2008, p. 5). This perspective stems from the medical model of disability, which focuses on an individual's limitations by viewing disability as a deficiency or deviation from the norm that requires cure, treatment, care and protection to alter the person so as to conform them to the existing social structures, processes and environments in which they live. This is an attempt to allow them to live a 'normal' life. Little emphasis is placed on the role the world and environment play in disabling people with impairments, thus well and truly earning the moniker 'the politics of disablement' (Oliver 1990). The medical model has existed at least since the advent of the Industrial Revolution (Oliver 1996) and sadly 'has guided and dominated clinical practice with the resulting assumption that both problems and solutions lie within disabled people rather than within society' (French 1994). As such, over the years the model has served to perpetuate negative and unhelpful attitudes and discriminatory practices that further oppress, ostracise and disable people with impairments (Finkelstein and Stuart 1996, pp. 175-76).

In a similar vein to 'curing' or 'eliminating' the harm of disability from the world are bioethical perspectives that strongly align with the medical model. A central tenet of bioethical study is the principle of beneficence, which comprises aims to achieve the two distinct, but related, goals of preventing harm and producing good (Smith 2012, p. 22). Of course, any application of this principle requires an advance assessment of three ethical dilemmas (Walters 1978, p. 50):

(1) what constitutes 'harm';

(2) what constitutes 'good';

(3) what are the possible negative social consequences that might come from new biomedical technologies in order to protect groups of individuals from that harm.

To the lay person, these propositions might appear to have subjective answers. The lay person would be right. However, utilitarian advocates of the medical model would hold that the best moral action in such a case is the one that maximises overall utility or benefit for the greatest number of people. To that end, Savulescu takes this basic bioethical creed a step further into the realm of disability and 
reproductive rights in claiming that a moral utilitarian principle of procreative beneficence exists (Savulescu et al. 2015). In summary, the principle requires that:

couples (or single reproducers) should select the child, of the possible children they could have, who is expected to have the best life, or at least as good a life as the others, based on the relevant, available information (Savulescu et al. 2015, p. 415).

The position is that through available technologies like CRISPR, parents should aim to remove 'disease genes', which cause a genetic disorder or predispose the person to the development of a disease. This perspective, essentially a form of eugenic practice disguised as mere biological reductionism, argues that it is irrational to choose an embryo that will not have the 'best life'. It further cloaks itself as a morally persuasive, rather than coercive, principle. Its final and most chilling formation is seen in the views of philosophers like Peter Singer, who believe that 'the killing of a disabled infant is not morally equivalent to killing a person. Very often it is not wrong at all' (Singer 1993, p. 191).

As this paper will soon show, in reality disabilities are generally not experienced as 'pain and suffering', nor are persons with disabilities 'harmed' by their impairment (Jones 2011b, p. 102). In actual fact, most of the suffering occurs as a 'result of not enough human caring, acceptance and respect' as a human being like others without a disability (Saxton 1988, p. 222). Even so, this crucial misconception underpinning the medical model and principle of procreative beneficence grounds a utilitarian argument that, in the same way it is morally wrong to harm another human, it is morally wrong to bring a person with a disability into the world on the basis of the pain and suffering it would bring onto the newborn (Harris 1990). The conclusion reached by Harris is that it is kinder to prevent the birth of a person with a disability (Harris 1998, p. 118; Marzano-Parisoli 2001). Any argument that such a world is morally preferable must rest on the assumption that 'a life with even moderate disabilities or impairments is a life with less moral value than other lives' (Bennett 2009, p. 271). Therefore, utilitarian individualism perceives people with disabilities as:

commodities to be 'serviced' and ... as an economic burden on society; their defects are emphasised and their worth is judged by their contribution to society. Being objects of charity, they are patronised and, at worst, they are perceived as dehumanised 'others' (Parmenter 2005, p. 53).

This paper disagrees with the proposition that whether a person will live a 'good' or 'best life' is wholly dictated merely by a genetic sequence or trait that forms part of who they are (Asch 2000; Shakespeare 1995). In that respect, there can be no effective regulation of genetic technology to safeguard human rights under these principles because, at a fundamental level, they do not conceive of a person with a disability as a 'full-value human'.

\subsection{The Social Model}

Whereas the medical model locates the problem in the impairment of the individual, the contrasting social model views disability as a social construct of discrimination and oppression that denies or limits personhood, beyond the individual's condition (Kayess and French 2008, p. 5; Degener 2014, p. 4). At the heart of the social model is the notion of 'systemic disadvantage', which is highlighted in the structural, social and exclusory barriers purposely or inadvertently erected by society (Oliver 1990, p. 47). Furthermore, the social model is based on a series of dichotomies, between impairment and disability, social and medical models, and persons with and without disabilities (Shakespeare 2013, p. 216). In relation to the distinction between the terms 'impairment' and 'disability, the former relates to the individual on a private level, whilst the latter relates to society on a structural level. Impairment refers to 'a characteristic, feature or attribute within an individual which is long term and may ... be the result of disease, genetics or injury' (Thomas et al. 1997, p. 2), and may affect appearance, function of mind or body and/or cause pain and fatigue. These physical, sensory, intellectual or psychological variations do not have to lead to disability unless society fails to 
accommodate and include people with those differences. Article 1 of the Convention on the Rights of Persons with Disabilities ('CRPD') provides an open definition of disability, such that it includes, but is not limited to 'those who have long-term physical, mental, intellectual or sensory impairments which in interaction with various barriers may hinder their full and effective participation in society on an equal basis with others' (United Nations 2007). In other words, disability is imposed over impairment by excluding individuals from being able to fully participate in society (Oliver 1996, p. 22). It is with these definitions in mind that we assess the relative merits and shortcomings of each conception of disability.

However, the social model has been criticised almost as much as the medical model (Shakespeare 2002). Whilst it has been instrumental in launching the disability movement, promulgating positive disability identity and encouraging barrier removal and rights legislation, it is ultimately a 'blunt instrument for explaining and combating the social exclusion that disabled people face, and the complexity of [their] needs' (Shakespeare 2013, p. 220). Its simplicity is its major flaw. In the context of human genetic engineering (or, in reality, any disruptive technology that affects the barriers people with disabilities might face) and CRISPR, utilisation of the social model, which lacks nuance, to underwrite any policy or regulatory rights protection regime is more difficult than it at first appears. Though the social model is indeed a useful tool for identifying systemic causes of disadvantage, it falls short in determining what action should be taken in response (Samaha 2007, p. 27). There is a disconnect between causation of the disability and policy, which produces an issue where the social model's account of causation forms the sole reason for social change (Samaha 2007, p. 37). The consequent issue then is that the resulting policy to remedy the issue is reactive. In a rapidly evolving technological landscape, to adequately protect the rights of persons with disabilities and other interest groups is not to retrospectively attempt to fix problems caused by scientific advancement, but rather to proactively create a global system of substantive and normative human rights.

Therefore, whilst a competent heuristic approach, the social model is imperfect (Degener 2014, p. 5). In light of the swift scientific advances made each week, if not each day, its utility is limited. Disability is an already complex issue made even more complex by the ethical and legal debate of genetic engineering. As such, we might be best served by a governance model underpinned by an alternative that more effectively allows for differing levels of analysis and policy.

\subsection{Human Rights and Dignitarianism: A Way Forward}

The third and final tenet of the bioethical and disability rights triad in the human genetic engineering debate is that of the emerging human rights model of disability and the complementary dignitarian ideology (Brownsword 2009, p. 25). This model builds upon the foundations of the social model and small aspects of the medical model, but goes further to enforce and protect the human rights of people with disabilities (Degener 2014, p. 29). First, it is contended that the anchor at the heart of modern human rights is the concept of human dignity (Degener and Quinn 2002, p. 30): a moral value attributable to each person by virtue of his or her humanity (Grant 2007) and independent of social status, gender, genetic makeup, physical or mental ability or any other characteristic (Basser 2011, pp. 19-20; Fukuyama 2002, pp. 14, 149). Human dignity is valuable especially for those who have traditionally been denied an equal place in society, because it reinforces the idea that all people are equal rights-bearers (Basser 2011, p. 21). Essentially, 'valuing human dignity means acknowledging the inherent worth of human beings; therefore violating dignity involves conveying the message that some are of less worth than others' (Reaume 2002-2003, p. 672).

In saying that, human dignity is a complex principle. It also involves a positive interpretation of 'humaneness' (Jones 2011a, p. 36). Basser elucidates four elements necessary for a person to be treated with dignity:

First is the absolutely crucial requirement that a person's physical integrity is respected ... Secondly, human dignity means that every person has the inherent right to be treated as an individual with a personality ... Thirdly, human dignity means that a person must be 
given voice about any issues which affect their lives and must have the ability wherever possible to exercise choice. Finally, inherent dignity of any individual requires that he or she has access to a fair share of the goods of society (Basser 2011, p. 19).

The human rights model centres on these principles of inherent human dignity by focusing on a person's medical characteristics only if absolutely necessary. It states that the 'problem' is extrinsic to the person and grants autonomy to the individual in relation to decisions or circumstances affecting him or her (Quinn and Degener 2002, p. 14). The human rights model differs from the social model in many respects, but most importantly, it explains why enforceable and inalienable human rights do not require an absence of impairment (Degener 2014, p. 6), includes a broader set of rights available to persons with disabilities, and values impairment as part of human diversity and variation.

As opposed to the views of Savulescu and Harris, the human rights model's fundamental critique of human genomic technologies is that their eventual widespread availability, use and probable misuse ultimately undermines, devalues and disempowers persons with disabilities unless rights safeguards are developed (Jones 2011b, p. 41). These threats have not gone unnoticed by the disability community. Such techniques are often seen to have the capacity to both threaten and to safeguard human dignity (McLean and Williamson 2007, p. 41). On the one hand, they may be viewed as supporting dignity of human life by improving health and alleviating suffering, such as by minimising the number of infants born with impairments and genetic disease or by respecting the reproductive liberty of those already born. On the other hand, eliminating or seeking to minimise the existence of people with genetic impairment may be perceived as offending human dignity, and thus human rights. From the latter perspective, DPI has posited the ethical and moral problems of more widely available genetic technology rather poignantly:

How can we live with dignity in societies that spend millions on genetic research to eradicate disease and impairment, but refuse to meet our needs to live dignified and independent lives? We cannot. We will not. The genetic threat to us is a threat to everyone. The value of life must not be reduced to a matter of genetic inheritance ((Disabled Peoples International DPI, p. 4)).

That being said, this paper does not posit that parents with children diagnosed with genetic disabilities and cognisant of their carrier status of the relevant genes are, in making reproductive decisions about the possibility of future offspring also being diagnosed with a genetic disability (such as prenatal diagnosis followed by pregnancy termination, or preimplantation genetic diagnosis), making judgments about the human dignity of their children already affected by the genetic condition. It is clear that any application of principles of human dignity to assess decisions made in relation to persons with genetic disabilities and their treatment must be more nuanced to avoid any such misconceptions.

This begs the question as to what role human dignity and the human rights model should play in ethically governing genetic development whilst protecting the rights and interests of persons with disabilities. Two conceptions of human dignity are relevant. The first conception is as a form of 'empowerment' by supporting individual autonomy (Brownsword 2009, p. 26). This is best exemplified in both the Universal Declaration of Human Rights ('UDHR'), which provides that 'all human beings are born free and equal in dignity and rights', and the CRPD, which aims to 'promote respect for [persons with disabilities'] inherent dignity' under Articles 1 and 3. The second conception is as a form of 'constraint' on the autonomy of scientists acting in ways that might infringe human rights (Brownsword 2009, p. 28). As will be discussed in Section 4, human dignity as constraint is axiomatic in the three UNESCO Declarations on bioethics and genetics, as well as the Council of Europe's Oviedo Convention. The centrality and prevalence of these concepts is the strongest support for the human rights model of disability and is therefore the best place to begin an analysis of the current legal system. 


\section{How Do We Regulate?}

The legal and ethical implications of manipulating the human genome depict a nebulous future. The globalisation of technological advances like CRISPR has exposed the absolute inadequacy of the development of nation-based bioethics for effectively addressing the threats raised by genomic technology (Lenzerini 2006, p. 292). Vast cross-jurisdictional inconsistency of legal genetic regulation may permit practices of uncertain morality and legality, such as human germline engineering, to develop in countries unwilling to enact such regulations. Ultimately, this paper emphasises the fact that, at present, the existing framework of human rights is likely systemically inadequate to address all threats to human dignity caused by rapid developments in biogenetics (Lenzerini 2006, p. 447; Iles 1996, p. 41).

\subsection{International Law}

As already noted, international law instruments such as the UDHR and UNESCO Declarations provide for human dignity both as an operational principle and moral precept (McCrudden 2008, pp. 668-71). For the purposes of genetics, this section will focus on two international law schemes: the CRPD and the UNESCO Declarations.

\subsubsection{CRPD}

The first point of reference for any discussion of disability human rights instruments in the common day must be the CRPD. The CRPD was the first UN human rights treaty adopted in the 21st Century and was reportedly the most rapidly negotiated ever (UN Secretary General 2006). It has been touted as a 'great landmark in the struggle to reframe the needs and concerns of persons with disabilities in terms of human rights' (Kayess and French 2008, p. 2). In regards to many issues that face persons with disabilities, it succeeds in protecting their rights. Articles 1 and 3(a) both emphasise the CRPD's agenda to codify the inalienable human rights of persons with disabilities by virtue of their human dignity, equal in scope and force with people without disabilities (Degener 2014, p. 7). A plethora of other articles comprehensively elucidate the many rights that others take for granted. On this, it should be commended.

However, from the particular perspective of human genome modification, the CRPD falls far short of effectively limiting potential abuses of CRISPR tools in the future. According to Wolbring and Diep (2016, p. 10) the CRPD could apply to gene editing in two ways:

(1) regulating the actual use of gene editing technologies like CRISPR; and

(2) in the aftermath of gene editing becoming more readily used, minimising the negative social consequences for persons with disabilities.

For a number of reasons, the potential application and substantive effectiveness of the CRPD in governing actual use of gene editing technologies is unclear.

First, the CRPD does not conceive of the potential impact of genetic technologies. Terms such as 'genetics', 'bioethics' or 'eugenics' do not feature once in the document. These glaring omissions highlight a fundamental lack of foresight as to the future threat genetic technologies and their misuse may pose to the disability human rights cause.

Second, though it is arguable that the anti-discrimination protections provided under Article 5 could validly critique pre or post-birth gene editing interventions aimed at 'fixing' impairment, the CRPD would be of little utility if gene editing interventions of any and all genes were permitted (Wolbring and Diep 2016, p. 12). This is again an example of how the purposes for which CRISPR and other gene editing technologies are used is crucial to their effective governance.

Third, a person's inherent right to life and its enjoyment on an equal basis with others under Article 10 remains starkly silent on 'genetic science aimed at the elimination of impairment-related human diversity and pre-birth negative selection of foeti with identified or imputed impairment' (Kayess and French 2008, p. 29). The further omission of such eugenic practices is a significant flaw. 
Fourth, Article 17, which states that 'every person with disabilities has a right to respect for his or her physical and mental integrity on an equal basis with others', is the most limited of the substantive rights. 'Physical integrity' clearly points towards internal physicalities of DNA makeup. A more robust right might have been useful in the context of human somatic and germline modification, but the statement is essentially confined to a principle with no specific application towards the human rights violations it purports to address. Therefore, the potential use of 'coercive State power for the purpose of 'treatment' remains without any specific regulation' (Kayess and French 2008, p. 30). It should be further noted that although Article 17 could draw attention to the involuntary treatments of a 'competent' adult. Even so, the right to physical and mental integrity is unlikely to apply if parents have genetic interventions performed on their children or embryos, or where adults with disabilities agree to genetic intervention (Wolbring and Diep 2016, p. 12).

Fifth, the general principle of 'respect for difference and acceptance of persons with disabilities as part of human diversity and humanity' articulated in Article 3 similarly expresses a principle with no application to particular situations. In this case, noting the role of eugenics or biological reductionism as grounds for failure to respect that difference would greatly improve the persuasive and moral force of the instrument.

Sixth, even if the above protections were more substantial, the definition of 'disabled people' under Article 1, whilst inclusive, appears to imply that embryos that have their somatic or germline cells modified and are adversely affected as a result (so as then to have a disability), would not have had any rights infringed as at the time of the modification because they did not have any human dignity upon which to infringe. This paper notes that whilst this regulatory 'gap' appears to exist, human dignity is arguably less effective in regulating the application of technologies like CRISPR to embryos. The conceptualisation of the moral and legal status of the embryo 'as a human' is an issue subject to a plethora of ethical, legal and religious complications that differ widely across and within countries. As such, this paper merely notes the wording of the CRPD to highlight that it might be less problematic for nation states to legislate with regard to these embryos instead, as will be discussed below in Section 4.2.

In contrast, the CPRD's role in preventing the deterioration of the lived experience of persons with disabilities following the rise of gene editing is slightly more promising. CRISPR may one day be used in genetic enhancement. 'Disability' under the CRPD is arguably a changing concept that includes future disability. Wolbring and Diep assert that the CRPD may be applicable to people who are currently considered non-disabled, but will be classified as disabled as ability expectations rise due to the prevalence of genetic and technological enhancement of human (Wolbring and Diep 2016, p. 14). Only time will tell whether, in mitigating these negative consequences, the CRPD will be used to demand access to particular genetic products and procedures or to restrict their use and, further, how robust such approaches will be.

Even so, the CRPD falls short, on balance, to adequately protect the rights of current and future persons with disabilities in respect of human genome engineering.

\subsubsection{UNESCO Declarations: Is Soft Law Tough Enough?}

Whilst not as recently endorsed as the CPRD, the UNESCO Declarations exist as a framework of non-binding international soft law that has specifically aimed to regulate bioethics at a universal level. The scheme comprises:

(1) The Universal Declaration on the Human Genome and Human Rights ('UDHGHR');

(2) The Universal Declaration on Bioethics and Human Rights ('UDBHR'); and

(3) The International Declaration on Human Genetic Data ('IDHGD').

Of the trio, the UDHGHR and UDBHR are the most relevant for present purposes. As such, the IDHGD will not be further discussed in this paper. The norms articulated in the UDHGHR and UDBHR, including the central tenets of human dignity and human rights, enjoy a wide consensus at the 
international level (El-Zein 2008, p. 318). In fact, they have become a legal and ethical reference point in the drafting of national laws and regulations around the world (Ida 2003, p. 368); a 'slow burn' influence. Nevertheless, it should be kept in mind that these Declarations are general in scope, and avoid dealing in specific detail with particular issues in biotechnology or bioethics. This was a deliberate choice by the UNESCO General Conference to proceed gradually and prudently (El-Zein 2008, p. 319). Even so, the provisions show a level of prescience as to the dangers the human race and persons with disabilities might face as human gene editing technology develops.

The UDHGHR aims to delineate and promulgate a universal ethical standard-setting framework that member States can and should utilise in determining and implementing their own bioethical policies. The Preamble takes as its starting point a cognisance of the potential advantages and dangers of human genomic research and applications, emphasising that 'such research should fully respect human dignity, freedom and human rights, as well as the prohibition of all forms of discrimination based on genetic characteristics'. It goes on to state a fundamental ethical principle of human rights and dignitarianism in Article 1:

The human genome underlies the fundamental unity of all members of the human family, as well as the recognition of their inherent dignity and diversity. In a symbolic sense, it is the heritage of humanity.

The reference to the genome as 'the heritage of humanity' is of particular relevance to the utility and moral viability of human germline gene modification. 'Heritage' has strong connotations with heritability. It therefore appears that, given the genome underpins our inherent human dignity and inclusive diversity, Article 1 attempts to discourage the artificial alteration of inheritable human germline cells. Following this definition, it is also recognised that there is a global responsibility on the international community as a whole to protect the disadvantaged, beyond single States and governments (International Bioethics Committee 2015, p. 27).

Clearly, the UDHGHR does not specifically denounce eugenic ideals. However, Lenzerini (2006, p. 318) asserts that Article 6 does provide a general prohibition against a range of conduct that would encompass discriminatory neo-eugenic practices through genetic experimentation in stating that:

No one shall be subjected to discrimination based on genetic characteristics that is intended to infringe or has the effect of infringing human rights, fundamental freedoms and human dignity.

Article 2 entrenches an individual's right to respect for their human dignity and diversity, rather than their value being reduced to a sum of their genetic characteristics. Article 3 further emphasises that the human genome is not static: it evolves over time. As such, the countless variations and mutations in our DNA and their potentialities are expressed and viewed differently depending on the individual's natural and social environment. When Articles 2, 3 and 6 are read in conjunction, the UDHGHR conveys a persuasive narrative of the importance of values like dignity, respect, uniqueness and diversity.

In turn, a cumulative reading of Articles 1, 2 and 6 highlights the overarching need to balance the possible positive and negative consequences associated with the growing prevalence of genetic technology. Most important for the purposes of safeguarding disability human rights are Articles 10 and 11. The former establishes the paramountcy of respect of human rights, freedoms and dignity of individuals of groups over research or research applications relating to the human genome. The latter forbids practices that are contrary to human dignity outright. This suggests that whilst knowledge is important for the advancement of the human race, it is the way in which that knowledge is utilised that determines whether human rights are violated by a subversion of human dignity (McLean and Williamson 2007, pp. 41-42).

Finally, Article 24 explicitly notes germline interventions as potentially contrary to human dignity. Though Article 24 is not a substantive protective right in itself, it does direct the International Bioethics Committee to make recommendations in relation to the identification, and arguably regulation, of such 
practices. By way of comparison, though Article 13 of the Oviedo Convention permits genome intervention for 'preventive, diagnostic or therapeutic purposes' (a point on which the UDHGHR is non-specific), it is pointedly made clear that this is so 'only if its aim is not to introduce any modification in the genome of any descendants' (emphasis added).

The relatively more modern UDBHR sheds further light on the proposed balance between individual rights and science referenced in the UDHGHR. Article 3 provides that human dignity, rights and fundamental freedoms are to be fully respected and, most importantly, 'the interests and welfare of the individual should have priority over the sole interest of science or society'. The content of such a provision is clear: the sanctity of human dignity and equality prevails over both the general interest to research and scientific progress and any other societal interest as a whole (Lenzerini 2006, p. 336).

These underlying principles militate against scholars like Savulescu, Singer and Harris interpreting provisions of the UDBHR in a manner consistent with utilitarian ideals of procreative beneficence, which arguably infringe human dignity. Article 4, for example, provides that:

In applying and advancing scientific knowledge, medical practice and associated technologies, direct and indirect benefits to patients, research participants and other affected individuals should be maximised and any possible harm to such individuals should be minimised.

Whilst proponents of procreative beneficence would argue that the direct and indirect benefits to persons with disabilities lie in their 'release' from or 'cure' of impairment, with little actual 'harm', it cannot be properly considered to be the object to which the UDBHR is put.

Moreover, Article 8 provides a marked improvement over Article 17 of the CRPD in that it provides a more specific application of the principle of personal integrity:

In applying and advancing scientific knowledge, medical practice and associated technologies, human vulnerability should be taken into account. Individuals and groups of special vulnerability should be protected and the personal integrity of such individuals respected.

The provision undoubtedly recognises that particular groups, like persons with disabilities, are especially susceptible to the adverse effects of misused genetic technologies. Researchers too must recognise, evaluate and re-evaluate the potentially far-reaching effects of their work at every stage, as required by Article 20. This continual cycle of risk assessment and management is imperative as a form of both self and peer-based regulation.

Finally, the UDBHR must necessarily defend the potential victims of discrimination. To that end, Article 11 mirrors Article 6 of the UDHGHR in that 'no individual or group should be discriminated against or stigmatised on any grounds, in violation of human dignity, human rights and fundamental freedoms.' Further, Article 14(2)(d) aims to direct the objectives of science and technology to the elimination of the marginalisation and the exclusion of persons on any grounds. Whether the whole of the scientific community will adhere to such broad dignity-based statements is unclear.

Despite its breadth, the applicability of the UDBHR may be restricted by the concession in Article 27 that these principles may be limited by state law in the interests of, among others, the protection of public health and the protection of the rights and freedoms of others. Again, it is unclear how a disability rights approach would contend with possibly competing notions of an 'obligation to let oneself be fixed' in the interests of public health frameworks, or the protection of the rights and freedoms of caregivers and others present in the lives of persons with disabilities (Wolbring and Diep 2016, p. 15). Further, a recurrent and seemingly endemic issue in instruments like the UNESCO Declarations in relation to human genetic engineering, is that an embryo cannot be seen to have human dignity so as to invoke the corresponding human rights (El-Zein 2008, p. 322).

In any case, the UNESCO universal soft law regime constitutes arguably the most comprehensive and solid foundation for the future international regulation of human genetic technology for both the 
interests of persons with disabilities and the broader human race. However, they are but a first step in such a difficult pursuit (El-Zein 2008, p. 318).

\subsection{State Domestic Law}

Despite the broad persuasive scope of such international instruments, they do not have any real binding force within each signatory nation state until domestic legislation to that effect is enacted. However, national policy frameworks governing human genome editing, both somatic and germline:

extend across a continuum that distinguishes between degrees of permissiveness, that is, between legally binding legislation and regulatory and/or professional guidance or research versus clinical applications (Isasi et al. 2016, p. 337).

As such, many of these national regimes aim to imitate international law's emphasis on human dignity and diversity by leaning towards taking a more prohibitive stance, at least in relation to human germline gene modification (Basser 2011, p. 36). Many countries ban human germline engineering (Araki and Ishii 2014, p. 116). However, the regulatory landscape suggests that it is not totally prohibited worldwide. The arrival of CRISPR has, and will continue to, disrupt medical, legal and ethical consensus even further.

Where legislation imposes a prohibition or restriction on germline interventions, it is generally paired with severe criminal sanctions that range from long imprisonment terms to significant fines (Isasi et al. 2016, p. 337; Center for Genetics and Society 2015). For example, the Australian position is quite severely prohibitive. Section 15(1) of the relevant Commonwealth law (Prohibition of Human Cloning for Reproduction and the Regulation of Human Embryo Research Amendment Act 2006) and Section 11(1) of the identical Victorian law (Prohibition of Human Cloning for Reproduction Act 2008) provides that a person commits an offence and may be imprisoned for up to 15 years if:

(1) the person alters the genome of a human cell in such a way that the alteration is heritable by descendants of the human whose cell was altered; and

(2) in altering the genome, the person intended the alteration to be heritable by descendants of the human whose cell was altered (emphasis added).

Furthermore, Sections 20(3) and 16(3) of each respective statute also criminalise the intentional placement of such an altered cell into the body of a woman. Both provisions require an element of mens rea, which gives rise to some uncertainty as to their potential enforceability. Nevertheless, the dual rationale for such provisions in preventing alteration of the 'heritage of humanity' is clear. First, there is an evolutionary imperative to refrain from making germline changes, the implications of which are currently unknown. Second, doing so fundamentally violates the principle of human dignity entrenched in the UNESCO Declarations. Relevantly, if either practice were to become widespread or commodified, that violation would be even more greatly focused on the dignity and value of persons with disabilities (Isasi et al. 2016, p. 337).

At the opposite end of the spectrum are countries with permissive approaches that aim to promote scientific progress because of its perceived benefit to humanity. Under policies adopted in China and the United Kingdom, research conducted for reproductive purposes is permitted under strict regulation and clinical applications are not expressly criminalised (Isasi et al. 2016, p. 337). Of the plethora of approaches worldwide, not one is necessarily completely right or wrong. However, global inconsistency may be eroded over time as one country's procedure eventually becomes the scientific and ethical standard (International Bioethics Committee 2015, p. 27). Given the rate that science is progressing and technologies like CRISPR are becoming more accurate, it is likely that the permissive approach will gain traction. Therefore, in the case of that eventuality, it is necessary to assess a regulatory model that will protect persons with disabilities in a pro-genetic era. 


\section{How Should We Regulate?}

In light of these shortfalls at both the international and national levels, this paper will attempt to posit a solution to the seemingly intractable issue of human gene editing research that has the greatest chance of a beneficial outcome for the disability and science communities alike. Two 'disclaimers' must be made at this juncture. First, this paper does not purport to propose a complete regulatory model per se, but rather a methodology to balance the interests of both the scientific and disability communities. Second, there is a general problem of inefficacy in legally regulating fast moving technologies like CRISPR. This paper contends that the most practical and ideal genetic research governance model is one grounded in human rights and dignity. It should involve a global discussion and consensus (insofar as is possible) including all relevant interest groups, especially those most likely to be disadvantaged by the use of gene editing technologies.

\subsection{Why a Human-Rights Based Regulatory Framework?}

There exist four potential oversight approaches to human germline editing technologies:

(1) a complete international ban;

(2) a temporary moratorium on research until ethical and scientific issues have been resolved;

(3) principled international and domestic regulation; or

(4) a laissez-faire approach (Bosley et al. 2015, pp. 383-85).

Given the heterogeneity of national ethical and legislative codes and the accessible cost of CRISPR, a complete ban or temporary moratorium will be virtually impossible to enforce worldwide (Altman et al. 2015, p. 26). Furthermore, a laissez-faire approach arguably creates the inevitable risk, especially in less stringently restricted countries, that research will be conducted before ethical due diligence. This could also lead to a patenting war, with all the likely unethical shortcuts that may entail, the winner of which will be granted enormous control over the development, scope and uses of CRISPR technology (Parthasarathy 2016). This leaves one option: regulation. Luckily, the institutional framework for regulation already exists in the UNESCO framework, national law and research guidelines. Nevertheless, an integrated and universal regulatory model must be actualised.

It is unclear exactly which form the regulatory model should take in order to remain effective and flexible whilst also instilling confidence in the people whose interests are to be protected. The broad literature on regulation yields many viable avenues. Whilst theories of decentralised or polycentric regulation (Black 2002, p. 4) often appear more applicable to the transnational context, they have had their legitimacy and accountability heavily criticised at that level. One promising framework that may be of great assistance in framing further debate on an appropriate and applicable model is Jonathan Kolieb's 'regulatory diamond' (Kolieb 2015), which builds on the seminal work of Ian Ayers and John Braithwaite in 'responsive regulation' theory (Ayres and Braithwaite 1992). The crux of responsive regulation is that regulatory instruments must adapt to the actions of the people or entities they aim to regulate. This determines the level of intervention required, and whether escalations or de-escalations are necessary over time.

However, a key shortcoming of the original Braithwaitian model was its sole focus on compliance with certain standards (Kolieb 2015, p. 143) and its corresponding omission in seeking improvement on the behaviour of those being regulated. The Koliebian model goes further in not only incorporating 'compliance regulation' (the regulatory mechanisms that encourage adherence to particular behavioural standards) but also 'aspirational regulation' (the regulatory mechanisms that encourage those regulated to improve their behaviour beyond minimal adherence to the minimum standards). The regulatory diamond points out that achieving compliance with legal requirements is only half of the solution to the problem being addressed. In this case, that problem is the growing viability and impact of genetic technologies. There is a powerful aspirational regulatory potential that has been untouched at this point. As Kolieb notes, from the perspective of a regulator: 
Their view of the regulated entity is no longer dominated by negative conceptions of an entity that needs to be curtailed and compelled to comply with minimum legal standards. With the diamond, the conception that pervaded responsive regulation theory is moderated by the understanding that regulated entities can also exceed such standards, and positively contribute to addressing the societal problem in question (Kolieb 2015, p. 161).

As CRISPR and other similarly disruptive technologies become more widespread, the inherent limitations of the law as a regulatory instrument mean that it should also be paired with other aspirational regulation instruments to drive researchers and private companies providing these services to act beyond the baseline legal requirements to secure the interests of persons with disabilities and other minorities as members of our society who might be adversely affected by the technologies. What such aspirational instruments might include will first depend on the minimum standard expected.

Then, putting aside aspirational regulation, why a model based on adherence to standards of human rights and dignity? There are multiple reasons for submitting CRISPR and other genetic technologies to regulation under the meta-norms of human rights and dignity:

(1) As highlighted in Section 4 of this article, the entirety of the UNESCO bioethical and human genome soft law framework is based on those foundational concepts. By mirroring those principles in a regulatory framework, it connects the legitimacy of UNESCO policy to the evolving international scientific and ethical practice (Somsen 2009, p. 114). Whilst there is no univocal ethic espoused in the Declarations, by and large the prevailing values are dignitarian and well suited to the current issue.

(2) An underlying ethic that focuses on the concept of human dignity as a constraint on autonomy is 'not only the most suitable for a liberal deliberative democracy' as in today's globalised society (Somsen 2009, p. 114), but is also the only possible answer to the reality of the disability community's disadvantaged position vis-à-vis continuous and rapid scientific advances like CRISPR (Fukuyama 1992; Brownsword 2004). The human rights model of disability is strongly complemented by, and shares largely the same objectives as, the idea of inherent human dignity. If the two ideas work in tandem, persons with disabilities will have the best chance at enacting beneficial reform at both international and national levels.

(3) A system of human rights and dignity has the potential to be flexible and adaptive to future technological change through the articulation of new international human rights principles specific to gene editing. The common acceptance of its underlying principles would also assist in its quick adoption by national regulatory agencies and parliaments (Mathews et al. 2015, p. 160). Whilst there is a considerable challenge in ensuring that such a regime is articulated clearly enough to be meaningful whilst not so broadly as to be arbitrary (Somsen 2009, p. 115), it is arguably the best theoretical framework at this point in time.

With these points in mind, we may conceptualise how best to formulate such a regime.

\subsection{The Way There}

Science is a global endeavour. As such, it is vital that nation-states and governments accept the principle of a shared global responsibility in relation to the editing of the human genome (International Bioethics Committee 2015, p. 27). An effective governance approach must be simple in operation, anticipatory and adaptive, and, most importantly in cases of disruptive technology, grounded in social acceptability after considering the views of all stakeholders (Reiss, p. 2). On social, ethical and evolutionary questions of this magnitude and nature, arguably the only way to achieve each of those objectives is through genuine collective discussion (Wolbring 2015, p. 446; Baker 2016, p. 273; Sarewitz 2015, p. 414; Araki and Ishii 2014, p. 18).

There are countless issues with universal governance of ethically polarising technologies, not the least of which are broad spectrum of secular, cultural and religious views of individuals, the public 
and government. Public policies on human gene editing range from prohibitionist, to regulated, to permissive. As such, it is likely unwise to set out, at least at this early stage, a comprehensive set of governance rules protecting human interests in the vain hope that they will be communicated, understood, implemented, obeyed and enforced overnight. Such thoughts are fanciful and of little assistance in resolving the ethical dilemma. On this point, Susan Peschin, the President and CEO of the Alliance for Ageing Research, stated that:

Principles generally serve to motivate people to do the things that seem good and right, but without the constraints and external pressure of specific rules. Introduce specific regulations on the safety and efficacy of gene editing and that starts to infringe on people's ethical limits, which traditional medical product regulation is not designed to address (Peschin 2017).

This paper agrees. We must first reach a normative consensus to effectively frame the broad international law, regulations and customs to eventually, and ideally, 'trickle down' into entrenched and more easily enforceable national laws. Though they will likely differ to various extents, the overarching principles will guide legislative bodies to an ethical governance model predicated on the protection of human dignity for all, including people with disabilities (Reiss, p. 5).

The 'Res-AGo-rA'1 research project, released in April 2016, offers a comprehensive governance framework for responsible research and innovation that ties in with the overarching human rights and dignity model. Essentially, it states that the first step in attaining some form of 'consensus' is for national ethical bodies and interest groups to come together to take responsibility for innovative advances and their societal consequences and draft agreed upon guidelines for research into gene editing (Lindner et al. 2016, p. 10). Richard Hayes, former Executive Director of the Centre for Genetics and Society, has expressed similar sentiments:

A productive next step might be to have a high-level task force representing the full range of constituencies with major stakes in these issues undertake a comprehensive review and assessment of options for global oversight and regulation (Hayes, p. 8).

Therefore, regulators and scientists must listen to public, community and civil society organisations and many others, who in turn must each listen to each other (Center for Genetics and Society and Friends of the Earth 2015, p. 39). Of course, numerous scholars have highlighted the importance of the disability justice refrain, 'Nothing About Us, Without Us', in having any legitimate discussion about the regulation of gene editing technologies (Shakespeare 2015, p. 446; Wolbring 2015; Benjamin 2016, p. 51; Thompson, p. 46; Knoppers 2016, p. 272). The voices of those from the disability community must be heard. Ultimately, any discussion and eventual consensus relating to human germline modification research and clinical use must adhere to the principles of human dignity outlined above and exemplified in the UNESCO Declarations.

Recently, a Committee composed of members of the National Academy of Science ('NAS') and the National Academy of Medicine ('NAM') embarked on the gargantuan task of addressing how we should regulate gene editing technologies like CRISPR. The Committee ultimately advocated a strong public participation model in developing any governance frameworks. In its deliberations, it focused in particular on:

(1) safeguarding and promoting individual health and wellbeing;

(2) cautiously approaching novel technologies in response to consistently changing information;

(3) respecting individual rights;

(4) warding against undesirable social consequences; and

1 Responsible Research and Innovation in a Distributed Anticipatory Governance Frame. A Constructive Socionormative Approach. 
(5) equally and equitably distributing information, burdens and benefits (National Academies of Sciences and Medicine 2017, p. 23).

Crucially, it established seven key principles foundational to the governance of human gene editing, even across national and cultural borders (National Academies of Sciences and Medicine 2017, p. 24):

(1) Promoting wellbeing: this principle aims to prevent harm by applying genome editing technologies to increase health and wellbeing whilst ensuring a reasonable balance of risk and benefit for any such application;

(2) Transparency: this principle encourages the free flow of information between stakeholders, including full, frank and timely disclosure and meaningful public input and debate in all aspects of policymaking for CRISPR and related technologies;

(3) Due care: this principle requires careful and deliberate conduct by researchers in relation to their patients, including appropriate supervision and consistent reassessment of risks, advances in technology and medicine, and cultural opinions;

(4) Responsible science: this principle serves to set and maintain high research standards in compliance with the norms of international society and the profession. This includes quality research design, review and evaluation, transparency, and the correction of false or misleading data or analysis;

(5) Respect for persons: this principle necessitates cognisance of the inherent human dignity of all people and the freedom of and respect for personal choice. Genetic characteristics are not indicative of any greater or lesser moral value. Further, respect for persons embodies active commitments to prevent neo-eugenics movements akin to the past, and to destigmatise disability;

(6) Fairness: this principle obliges us to treat all equally, including in distributing risks and benefits of research and enabling the equitable access to resulting clinical applications of human gene editing;

(7) Transnational cooperation: this principle highlights the immense need for collaboration in both research and regulation, whilst accommodating for different cultural perspectives. Adherence requires, where possible, coordination of international regulatory standards and processes, and data sharing between scientific communities and regulatory authorities.

This paper cannot find evident faults with these principles. They are neither too broad and meaningless, nor narrow and overly restrictive, in that they allow space for nations to comply in their own ways, but with common and consistent objectives. There appears to be no set hierarchy or priority to any one value over the other, though this paper notes that the principles relating to respect to persons and fairness are obviously vital for the preservation of the interests of persons with disabilities.

As to what the content of any policy instruments that arise out of discussions, this paper cannot say in any great detail. A number of such instruments have been proposed in the past, including:

- A 2002 proposal, which called for a 'Convention on the Preservation of the Human Species', aimed to prohibit human reproductive cloning and human germline genetic modification, and establish national oversight systems that ensured that use of gametes or embryos met consent, safety and ethical standards (Annas et al. 2002).

- A 2007 proposal, which asserted that the concept of a complete ban on human reproductive cloning had essentially attained the status of customary international law, to codify this into an international instrument under the UNESCO framework (Kuppuswamy et al. 2007).

- A 2008 proposal, which posited a 'Genetic Heritage Safeguard Treaty' based on the 1970 Nuclear Nonproliferation Treaty, to serve the dual function of both encouraging responsible applications of human genetic research as well as delineating limits on those applications deemed 'undesirable' (Metzl 2008).

Whatever the future may hold, this paper hopes for a respectful and coherent debate and an influential international instrument (or at the very least, a series of regionalised instruments) that prioritises 
respect for and protection of human dignity of people with disabilities and other possibly marginalised groups over more scientific and neo-eugenic agendas in human genome editing.

\section{Conclusions}

The unprecedented speed of technological development in human genome editing in recent years is testament to the globalised scientific community's unyielding passion for knowledge. Yet, even with such a (hopefully) noble motivation, innovations such as CRISPR have the potential to be utilised as tools of neo-eugenics. If they were so used, especially in germline intervention, the potential ramifications on the rights and ways of life of members of the disability community are numerous and far-reaching. Through an analysis of bioethical principles and traditional and modern conceptions of disability, this paper suggests that human dignity is the core moral precept and value on which modern international and domestic law frameworks operate in this ethically problematic sphere. Furthermore, there are significant flaws, gaps and uncertainties in the existing regulatory system. This is not the place to suggest a new set of international bioethical guidelines to govern human genome editing whilst preserving the human rights of persons with disabilities; that is an issue for wide deliberation and consensus. Instead, this paper proposes a mechanism by which a new human-rights-based regulatory instrument may be conceived to benefit both the disability and science communities. A set of clearly articulated principles will set the necessary debate and discussion on the right course. Nevertheless, the time for action is now. As increasingly accurate genome editing technology proliferates across national borders, a coherent and cohesive international stance on the issue is more urgently needed than ever. Time waits for no human right.

Conflicts of Interest: The author declares no conflict of interest.

\section{References}

Altman, Russ B., Shamik Mascharak, and Niklaus Evitt. 2015. Human Germline Crispr-Cas Modification: Toward a Regulatory Framework. American Journal of Bioethics 15: 25-29.

Amundson, Ron, and Shari Tresky. 2008. Bioethics and Disability Rights: Conflicting Values and Perspectives. Bioethical Inquiry 5: 111-23. [CrossRef]

Annas, George J., Lori B. Andrews, and Rosario M. Isasi. 2002. Protecting the Endangered Human: Toward an International Treaty Prohibiting Cloning and Inheritable Alterations. American Journal of Law E Medicine 28: 151-78.

Araki, Motoko, and Tetsuya Ishii. 2014. International Regulatory Landscape and Integration of Corrective Genome Editing into in Vitro Fertilization. Reproductive Biology and Endocrinology 12: 108. [CrossRef] [PubMed]

Asch, Adrienne. 2000. Why I Haven't Changed My Mind about Prenatal Diagnosis: Reflections and Refinements. Prenatal Testing and Disability Rights. Edited by Erik Parens and Adrienne Asch. Washington: Georgetown University Press.

Ayres, Ian, and John Braithwaite. 1992. Responsive Regulation: Transcending the Deregulation Debate. Oxford: Oxford University Press.

Bachruch, Susan. 2004. In the Name of Public Health—Nazi Racial Hygeine. New England Journal of Medicine 351: 417-20. [CrossRef] [PubMed]

Baker, Beth. 2016. The Ethics of Changing the Human Genome. BioScience 66: 267-73. [CrossRef]

Baldi, Pierre. 2001. The Shattered Self: The End of Natural Evolution. Cambridge: MIT Press.

Baltimore, David, Paul Berg, Michael Botchan, Dana Carroll, R. Alta Charo, George Church, Jacob E. Corn, George Q. Daley, Jennifer A. Doudna, Marsha Fenner, and et al. 2015. A Prudent Path Forward for Genomic Engineering and Germline Gene Modification. Science 348: 36-38. [CrossRef] [PubMed]

Baruch, Susannah, Audrey Huang, Daryl Pritchard, Andrea Kalfoglou, Gail Javitt, Rick Borchelt, Joan Scott, and Kathy Hudson. 2005. Human Germline Genetic Modification: Issues and Options for Policymakers. Baltimore: Genetics and Public Policy Center, Johns Hopkins University Berman Institute of Bioethics.

Basser, Lee Ann. 2011. Human Dignity. In Critical Perspectives on Human Rights and Disability Law. Edited by Marcia H. Rioux, Lee Ann Basser and Melinda Jones. Leiden: Martinus Nijhoff Publishers, pp. 17-36. 
Benjamin, Ruha. 2016. Interrogating Equity: A Disability Justice Approach to Genetic Engineering. Issues in Science \& Technology 32: 50-54.

Bennett, Rebecca. 2009. The Fallacy of the Principle of Procreative Beneficence. Bioethics 23: 265-73. [CrossRef] [PubMed]

Black, Edwin. 2008. War against the Weak: Eugenics and America's Campaign to Create a Master Race. New York: Dialog Press.

Black, Julia. 2002. Critical Reflections on Regulation. Australian Journal of Legal Philosophy 27: 1-46.

Bosley, Katrine S., Michael Botchan, Annelien L. Bredenoord, Dana Carroll, R. Alta Charo, Emmanuelle Charpentier, Ron Cohen, Jacob Corn, Jennifer Doudna, Guoping Feng, and et al. 2015. Crispr Germline Engineering-The Community Speaks. Nature Biotechnology 33: 478-86. [CrossRef] [PubMed]

Breggin, Peter. 1993. Psychiatry's Role in the Holocaust. International Journal of Risk E Safety in Medicine 4: 133-48.

Brosius, Jurgen, and Martin Kreitman. 2000. Eugenics-Evolutionary Nonsense? Nature Genetics 25: 253. [CrossRef] [PubMed]

Brownsword, Roger. 2004. What the World Needs Now: Techno-Regulation, Human Rights and Human Dignity. In Global Governance and the Quest for Justice. Edited by Roger Brownsword. Oxford: Hart Publishing, p. 203.

Brownsword, Roger. 2009. Human Dignity, Ethical Pluralism, and the Regulation of Modern Biotechnologies. In New Technologies and Human Rights. Edited by Thérèse Murphy. New York: Oxford University Press, pp. 19-84.

Burleigh, Michael. 1994. Death and Deliverance: 'Euthanasia' in Germany, C.1900 to 1945. Cambridge: Cambridge University Press.

Center for Genetics and Society. 2015. Human Germline Modification: Summary of National and International Policies. Berkeley: Centre for Genetics and Society.

Center for Genetics and Society and Friends of the Earth. 2015. Extreme Genetic Engineering and the Human Future: Reclaiming Emerging Biotechnologies for the Common Good. Berkeley: Center for Genetics and Society.

Council for Responsible Genetics. 2005. Position Paper on Human Germline Manipulation. Cambridge: Council for Responsible Genetics.

Degener, Theresia. 2014. A Human Rights Model of Disability. Available online: http://www.academia.edu/ 18181994/A_human_rights_model_of_disability (accessed on 10 June 2016).

Degener, Theresia, and Gerard Quinn. 2002. Survey of International, Comparative and Regional Disability Law Reform. In Disability Rights Law and Policy: International and National Perspectives. Edited by Silvia Yee and Mary Lou Breslin. Leiden: Martinus Nijhoff.

Disabled Peoples International (DPI). 2000. Disabled People Speak on the New Genetics: DPI Europe Position Statement on Bioethics and Human Rights. London: DPI Europe.

Doudna, Jennifer A. 2015. How Crispr Lets Us Edit Our DNA. London: TEDGlobal, Transcript.

Dzau, Victor J., and Ralph J. Cicerone. 2015. Responsible Use of Human Gene-Editing Technologies. Human Gene Therapy 26: 411-12. [CrossRef] [PubMed]

El-Zein, Souheil. 2008. International Regulation of Human Genetics. In Genetic Engineering and the World Trade System. Edited by Daniel Wuger and Thomas Cottier. New York: Cambridge University Press, p. 315.

Esvelt, Kevin M., and Harris H. Wang. 2013. Genome-Scale Engineering for Systems and Synthetic Biology. Molecular Systems Biology 9: 641. [CrossRef] [PubMed]

Finkelstein, Vic, and Ossie Stuart. 1996. Developing New Services. In Beyond Disability: Towards an Enabling Society. Edited by Gerard Hales. London: SAGE Publications.

Fischer, Bernard A. 2012. Maltreatment of People with Serious Mental Illness in the Early 20th Century: A Focus on Nazi Germany and Eugenics in America. Journal of Nervous and Mental Disease 200: 1096-100. [CrossRef] [PubMed]

French, Phillip. 1994. What Is Disability? In On Equal Terms—Working with Disabled People. Edited by Phillip French. Oxford: Butterworth-Heinemann.

Fukuyama, Francis. 1992. The End of History and the Last Man. New York: Free Press.

Fukuyama, Francis. 2002. Our Posthuman Future: Consequences of the Biotechnology Revolution. New York: Farrar, Strauss and Giroux.

Galton, Francis. 1883. Inquiries into Human Faculty and Development. London: Macmillan.

Grant, Evadné. 2007. Dignity and Equality. Human Rights Law Review 7: 299-329. [CrossRef]

Harris, John. 1990. The Wrong of Wrongful Life. Journal of Law \& Society 17: 90-105. 
Harris, John. 1998. Clones, Genes and Immortality: Ethics and the Genetic Revolution. Oxford: Oxford University Press.

Hayes, Richard. 2008. Is There an Emerging International Consensus on the Proper Uses of the New Human Genetic Technologies? Paper presented at the US House of Representatives Foreign Affairs Committee Subcommittee on Terrorism, Nonproliferation and Trade Hearing on Genetics and Other Human Modification Technologies: Sensible International Regulations or a New Kind of Arms Race? Los Angeles, CA, USA, June 19.

Herberer, Patricia. 2002. Targeting the "Unfit" and Radical Public Health Strategies in Nazi Germany. In Deaf People in Hitler's Europe. Edited by Donna F. Ryan and John S. Schuchmann. Washinton: Gallaudet University Press.

Hoge, Stephen K., and Paul S. Appelbaum. 2012. Ethics and Neuropsychiatric Genetics: A Review of Major Issues. International Journal of Neuropsychopharmacology 15: 1547-57. [CrossRef] [PubMed]

Hsu, Patrick D., Eric S. Lander, and Fenc Zhang. 2014. Development and Applications of Crispr-Cas9 for Genome Engineering. Cell 157: 1262-78. [CrossRef] [PubMed]

Ida, Ryuichi. 2003. Bioethics and International Law. In Ordine Internazionale E Valori Etici. Edited by Nerina Boschiero. Verona: Societa Italiana di Diritto Internazionale, p. 365.

Iles, Alastair T. 1996. The Human Genome Project: A Challenge to the Human Rights Framework. Harvard Human Rights Journal 9: 27-60. [PubMed]

Imparato, Andrew J. 2004. Testimony: Senate Hearing on Prenatal Genetic Testing Technology. Washington: United States Congress, Committee on Commerce, Science, and Transportation, Subcommittee on Science, Technology, and Space.

International Bioethics Committee. 2015. Report of the Ibc on Updating Its Reflection on the Human Genome and Human Rights. Paris: UNESCO.

Isasi, Rosario, Erika Kleiderman, and Bartha Maria Knoppers. 2016. Editing Policy to Fit the Genome? Science 351: 337-39. [CrossRef] [PubMed]

Ishii, Tetsuya. 2015. Germ Line Genome Editing in Clinics: The Approaches, Objectives and Global Society. Briefings in Functional Genomics. Available online: http:/ /bfg.oxfordjournals.org/content/early/2015/11/ 27/bfgp.elv053.full (accessed on 14 June 2016).

Jones, Melinda. 2011a. Introduction: Dignity. In Critical Perspectives on Human Rights and Disability Law. Edited by Marcia H. Rioux, Lee Ann Basser and Melinda Jones. Leiden: Martinus Nijhoff Publishers, pp. 85-86.

Jones, Melinda. 2011b. Valuing All Lives-Even “Wrongful” Ones. In Critical Perspectives on Human Rights and Disability Law. Edited by Marcia H. Rioux, Lee Ann Basser and Melinda Jones. Leiden: Martinus Nijhoff Publishers, pp. 87-116.

Kayess, Rosemary, and Phillip French. 2008. Out of Darkness into Light? Introducing the Convention on the Rights of Persons with Disabilities. Human Rights Law Review 8: 1-34. [CrossRef]

King, David. 2001. Eugenic Tendencies in Modern Genetics. In Redesigning Life? The Worldwide Challenge to Genetic Engineering. Edited by Brian Tokar. London: Zed Books, pp. 171-81.

Knoppers, Bartha Maria. 2016. Human Gene Editing: Principles \& Precedents. Available online: http:// nationalacademies.org/cs/groups/genesite/documents/webpage/gene_172445.pdf (accessed on 3 May 2017).

Kolieb, Jonathan. 2015. When to Punish, When to Persuade and When to Reward: Strengthening Responsive Regulation with the Regulatory Diamond. Monash University Law Review 41: 136-63.

Kuppuswamy, Chamundeeswari, Darryl Macer, Mihaela Serbulea, and Brendan Tobin. 2007. Is Human Reproductive Cloning Inevitable: Future Options for UN Governance. Tokyo: United Nations University Press.

Lander, Eric S. 2015. Brave New Genome. New England Journal of Medicine 373: 5-8. [CrossRef] [PubMed]

Lanphier, Edward, Fyodor Urnov, Sarah Ehlen Haecker, and Michael Werner. 2015. Don't Edit the Human Germ Line. Nature 519: 410-11. [CrossRef] [PubMed]

Ledford, Heidi. 2015. Crispr, the Disruptor. Nature 522: 20-24. [CrossRef] [PubMed]

Lenzerini, Federico. 2006. Biotechnology, Human Dignity and the Human Genome. In Biotechnology and International Law. Edited by Francesco Francioni and Tullio Scovazzi. Portland: Hart Publishing, pp. 285-340.

Liang, Puping, Yanwen Xu, Xiya Zhang, Chenhui Ding, Rui Huang, Zhen Zhang, Jie Lv, Xiaowei Xie, Yuxi Chen, Yujing Li, and et al. 2015. Crispr/Cas9-Mediated Gene Editing in Human Tripronuclear Zygotes. Protein \& Cell 6: 363-72.

Lindner, Ralf, Stefan Kuhlmann, Sally Randles, and Bjørn Bedsted. 2016. Navigating towards Shared Responsibility. Brussels: ResAGora.

Marzano-Parisoli, Maria Michela. 2001. Disability, Wrongful-Life Lawsuits, and the Human Difference: An Exercise in Ethical Perplexity. Social Theory and Practice 27: 637-59. [CrossRef] 
Mathews, Debra J. H., Sarah Chan, Peter J. Donovan, Thomas Douglas, Christopher Gyngell, John Harris, Alan Regenberg, and Robin Lovell-Badge. 2015. Crispr: A Path through the Thicket. Nature 527: $159-61$. [CrossRef] [PubMed]

McCrudden, Christopher. 2008. Human Dignity and Judicial Interpretation of Human Rights. European Journal of International Law 19: 655-724. [CrossRef]

McLean, Sheila, and Laura Williamson. 2007. Impairment and Disability: Law and Ethics at the Beginning and End of Life. London: Routledge.

Menand, Louis. 2004. The Science of Human Nature and the Human Nature of Science. In Genetics, Disability, and Deafness. Edited by John Vickrey Van Cleve. Washington: Gallaudet University Press, pp. 5-22.

Metzl, Jamie. 2008. Brave New World War. Center for Genetics and Society. Available online: http://www. geneticsandsociety.org/article.php?id=3985 (accessed on 1 June 2016).

National Academies of Sciences and Medicine. 2015. On Human Gene Editing: International Summit Statement. Washington: National Academies of Sciences and Medicine.

National Academies of Sciences and Medicine. 2017. Human Genome Editing: Science, Ethics, and Governance. Washington: National Academies Press.

Oliver, Michael. 1990. The Politics of Disablement. Basingstoke: Palgrave Macmillan.

Oliver, Michael. 1996. Understanding Disability: From Theory to Practice. New York: St. Martin's Press.

Parmenter, Trevor R. 2005. Are We Engineering Ourselves out of Existence? Journal of Intellectual and Developmental Disability 30: 53-56. [CrossRef]

Parthasarathy, Shobita. 2016. Crispr Dispute Raises Bigger Patent Issues That We're Not Talking about. The Conversation. April 4. Available online: https://theconversation.com/crispr-dispute-raises-bigger-patent-issues-thatwere-not-talking-about-56715 (accessed on 13 June 2016).

Peschin, Susan. 2017. How Should We Regulate Genome Editing? World Economic Forum. Available online: https:/ / www.weforum.org/agenda/2017/05/how-should-we-regulate-genome-editing/ (accessed on 2 June 2017).

Pollack, Robert. 2015. Eugenics Lurk in the Shadow of CRISPR. Science 348: 871. [CrossRef] [PubMed]

President's Council on Bioethics. 2003. Beyond Therapy: Biotechnology and the Pursuit of Happiness. Washington: President's Council on Bioethics.

Proctor, Robert N. 1988. Racial Hygeine: Medicine under the Nazis. Cambridge: Harvard University Press.

Quinn, Gerard, and Theresia Degener. 2002. The Current Use and Future Potential Use of United Nations Human Rights Instruments in the Context of Disability. New York and Geneva: Office of the United Nations High Commissioner for Human Rights.

Reaume, Denise G. 2002-2003. Discrimination and Dignity. Louisiana Law Review 63: 645-96.

Reiss, Thomas. 2015. Governance Approaches for Human Gene Editing Based on Responsible Research and Innovation. Paper presented at the National Academies of Sciences and Medicine's International Summit on Human Gene Editing, Washington, DC, USA, December 1-3.

Samaha, Adam. 2007. What Good Is the Social Model of Disability? The University of Chicago Law Review 74: 166. [CrossRef]

Sarewitz, Daniel. 2015. Crispr. Science Can't Solve It. Nature 522: 413-14. [CrossRef] [PubMed]

Savulescu, Julian, Jonathan Pugh, Thomas Douglas, and Christopher Gyngell. 2015. The Moral Imperative to Continue Gene Editing Research on Human Embryos. Protein E Cell 6: 476-79.

Saxton, Marsha. 1988. Prenatal Screening and Discriminatory Attitudes About Disability. Women and Health 13: 217-24. [CrossRef]

Shakespeare, Tom. 1995. Back to the Future? New Genetics and Disabled People. Critical Social Policy 44: 22-35. [CrossRef]

Shakespeare, Tom. 2002. The Social Model of Disability: An Outdated Ideology? Research in Social Science and Disability 2: 9-28.

Shakespeare, Tom. 2013. The Social Model of Disability. In The Disability Studies Reader. Edited by Lennard J. Davis. Abingdon: Routledge.

Shakespeare, Tom. 2015. Gene Editing: Heed Disability Views. Nature 527: 446. [CrossRef] [PubMed]

Singer, Peter. 1993. Practical Ethics, 2nd ed. Cambridge: Cambridge University Press.

Smith, George P., II. 2012. Law and Bioethics: Intersections Along the Mortal Coil. Abingdon: Routledge. 
Somsen, Han. 2009. Regulating Human Genetics in a Neo-Genetic Era. In New Technologies and Human Rights. Edited by Thérèse Murphy. New York: Oxford University Press, pp. 85-127.

Thomas, Pam, Lorraine Gradwell, and Natalie Markham. 1997. Defining Impairment within the Social Model of Disability. Greater Manchester Coalition of Disabled People. Available online: http:/ / disability-studies.leeds.ac. uk/files/library/thomas-pam-Defining-Impairment-within-the-Social-Model-of-Disability.pdf (accessed on 29 May 2016).

Thompson, Charis. 2015. Governance, Regulation, and Control: Of Which People, by Which People, for Which People? Paper presented at the National Academies of Sciences and Medicine's International Summit on Human Gene Editing, Washington, DC, USA, December 1-3.

Turmusani, Majid. 2004. Genetic Technology and the UN Disability Convention. Disability World. Available online: http:/ / www.disabilityworld.org/12-02_05/news/genetictech.shtml (accessed on 3 June 2016).

UN Secretary General. 2006. Secretary-General Hails Adoption of Landmark Convention on Rights of People with Disabilities. SG/SM/10797-HR/4911-L/T/4400. December 3. Available online: http://www.un.org/ press/en/2006/sgsm10797.doc.htm (accessed on 8 June 2016).

United Nations. 2007. UN Convention on the Rights of Persons with Disabilities, opened for signature 30 March 2007, 999 UNTS 3 (entered into force 3 May 2008).

Walters, LeRoy. 1978. Bioethics as Field of Ethics. In Contemporary Issues in Bioethics. Edited by Tom L. Beauchamp and LeRoy Walters. Los Angeles: Calif Dickenson, p. 49.

Witzany, Guenther. 2016. No Time to Waste on the Road to a Liberal Eugenics? EMBO Reports 17: 281. [CrossRef] [PubMed]

Wolbring, Gregor. 2015. Gene Editing: Govern Ability Expectations. Nature 527: 446. [CrossRef] [PubMed]

Wolbring, Gregor, and Lucy Diep. 2016. The Discussions around Precision Genetic Engineering: Role of and Impact on Disabled People. Laws 5: 37. [CrossRef]

(C) 2017 by the author. Licensee MDPI, Basel, Switzerland. This article is an open access article distributed under the terms and conditions of the Creative Commons Attribution (CC BY) license (http:/ / creativecommons.org/licenses/by/4.0/). 